\title{
PRODUCT PROMOTIONAL STRATEGIES \\ ON A CHINESE SHOPPING WEBSITE: THE MULTIMODAL FUSION MODEL
}

\section{Introduction}

In recent years, China has become one of the most important markets in the world due to globalization. ${ }^{1}$ As the Chinese market is very competitive, sellers have to look for new marketing channels to promote their products. As a result, internet marketing communication, such as online advertising, plays a significant role in Chinese economic development. The main purpose of online advertising is to influence current and potential consumers' purchasing choices. Additionally, the widespread use of smartphones and other hand-held and portable electronic devices has also had a great impact on the everyday life of Chinese people. According to Lu, many cities in China have become cashless and cardless, and around $40 \%$ of Chinese people carry almost no cash when going out. ${ }^{2}$

The number of mobile internet users in China is growing rapidly. Clearly, mobile text advertising has become important in promoting products in modern China. As indicated by Lin and Chen in their study on how mobile text advertising has influenced consumer purchasing, "consumers use smartphones not only for communication but also for other activities, such as surfing the web and participating in mobile business". " Indeed, China's electronic commerce market has grown more rapidly than in any other country in the world in recent years. Millions of people are engaged in online shopping as a daily event and see hundreds of thousands of promoted items. As such, the enormous potential that online marketing has for

* ORCID: 0000-0002-3167-3959, DOI: 10.4467/23538724GS.20.054.13494

** ORCID: 0000-0002-1783-4381, DOI: 10.4467/23538724GS.20.054.13494

1 C. Lattemann, I. Alon, J. Chang, M. Fetscherin, J.R. McIntyre, The globalization of Chinese enterprises, “Thunderbird International Business Review” 2012, vol. 54, no. 2, pp. 145-153.

2 L. Lu, Decoding Alipay: Mobile payments, a cashless society and regulatory challenges, "Butterworths Journal of International Banking and Financial Law" 2018, vol. 33, no. 1, pp. 40-43.

$3 \mathrm{H}$. Lin, Z. Chen, Effects of mobile text advertising on consumer purchase intention: A moderated mediation analysis, "Frontiers in Psychology" 2017, vol. 8, p. 1022. 
individual businesses is clear and this new advertising medium makes this way of communication a direct extension of traditional offline marketing practices.

Interestingly, advertisements are not only adjusted according to people's needs. They may also have a significant impact on people's lives. As argued by Reczek et al., targeted advertisements do not simply make consumers more likely to purchase the items promoted; these advertisements may also change how consumers think about themselves. ${ }^{4}$ As such, the purpose of our study is to analyze the product promotional strategies used by online sellers in China so that we may better understand how the purchase intentions of Chinese consumers are manipulated by online advertisements.

\section{Database}

The data used in this study were drawn from Taobao (taobao.com), one of the world's biggest electronic commerce websites, between November 3, 2017 and February 3, 2018. Our findings are based on 100 clothing advertisements on this online shopping website -50 for men's clothing and 50 for women's clothing. Each advertisement comprises a picture/pictures and text. The largest number of characters used in one advertisement was 145, and the smallest number was 4 characters. The advertisements used in this analysis were selected according to their popularity ranking on Taobao.

In transcribing the Mandarin text, Hàny̌̌ Pinyin 'Transcription of Chinese Characters' was used. Due to the fact that Mandarin is a tonal language, the tone is marked on the vowel. The high-level tone is marked as '-', the rising tone marked as "', the falling-rising tone marked as "', the falling tone marked as ", , and finally the neutral tone is left unmarked. In presenting the textual message, the Chinese characters and their transcription are accompanied by an English translation provided by the authors. In addition to the above, important words are highlighted in bold type.

\section{The multimodal fusion model}

It is not easy to identify the impact of the advertising messages and their influence on purchasing decisions. As a result, many previous studies on advertising have tended to focus on specific elements of advertisements, such as: the various forms

\footnotetext{
4 R.W. Reczek, C. Summers, R. Smith, Targeted ads don't just make you more likely to buy - They can change how you think about yourself, 2016, https://hbr.org/2016/04/targeted-ads-dont-just-makeyou-more-likely-to-buy-they-can-change-how-you-think-about-yourself (accessed: 11.11.2020).
} 
of expression used in advertising, e.g. image or color ${ }^{5}$ the content of the advertising message and advertisement composition; ${ }^{6}$ and rational and emotional communication in advertising. ${ }^{7}$ While the findings of the above studies could most likely be combined to give us a general picture of what advertisements are like, they have left out two important aspects of analysis - the conceptual and linguistic modes.

Lin and Chiang have proposed a multimodal fusion model to account for the cognitive mechanism encoded in political cartoons. ${ }^{8}$ They argue that this multimodal fusion model evolves from both the related metonymic network and the diversified metaphoric network, combining the conceptual, visual, and verbal modes. This model is distinguished from visual 'fusion' widely discussed in advertisement analysis," as multimodal fusion should be defined as "when the target and the source are visually, verbally, and conceptually amalgamated". ${ }^{10} \mathrm{Al}-$ though the multimodal fusion model was originally used to analyze cartoons, it can successfully be used to analyze online advertisements. By adopting this analytic approach, we can begin to understand how graphic and textual elements are combined to grab the attention of consumers, as well as how the fusion of both these elements cognitively influences the consumer's decision. Specifically, we aim to understand why a particular advertisement makes the consumer believe that they would be better off with the product.

\section{Sample analysis of product promotional strategies}

Analyzing the data, we observed that online sellers and stores on Taobao frequently use the following four strategies to promote their products in their advertisements: 1) expressing closeness and solidarity with current and potential consumers; 2) creating humor; 3) suggesting the advantages of purchasing a product; and 4) highlighting the benefits of a product. These four product promotional strategies will be qualitatively analyzed below.

5 M.M. Evans, A. Jamal, G. Foxall, Consumer Behavior, 2nd ed., West Sussex 2011.

6 D. Doliński, Psychologiczne mechanizmy reklamy [Psychological Mechanisms of Advertising], Gdańsk 2003.

D. Doliński, Psychologia wptywu społecznego [Psychology of Social Influence], Wrocław 2000; E.M. Berg, L.G. Lippman, Does humor in radio advertising affect recognition of novel product brand names?, "Journal of General Psychology" 2001, vol. 128, no. 2, pp. 194-205.

8 T.Y.-Y. Lin, W.-Y. Chiang, Multimodal fusion in analyzing political cartoons: Debates on U.S. beef imports into Taiwan, "Metaphor and Symbol" 2015, vol. 30, pp. 137-161.

9 C.J. Forceville, Pictorial Metaphor in Advertising, New York - London 1996; C.J. Forceville, Non-verbal and multimodal metaphor in a cognitive framework: Agendas for research [in:] Cognitive Linguistics: Current Applications and Future Perspectives, eds. G. Kristiansen, M. Achard, R. Dirven, F.J.R. de Mendoza Ibáñez, Berlin - New York 2006, pp. 379-402.

10 T.Y.-Y. Lin, W.-Y. Chiang, Multimodal fusion..., p. 138. 
1. Expressing closeness and solidarity with current and potential consumers

To increase purchase intentions for promoted products among current and potential consumers, it is very important to establish a close relationship with them. As such, it is useful to express closeness and solidarity with current and potential consumers. In our data, we observed that personal pronouns and questions can be used for this purpose.

\subsection{The employment of personal pronouns}

Person deixis is concerned with the grammatical category of person and reflects how a participant role is encoded in a speech event. ${ }^{11}$ More specifically, personal pronouns can be used in many ways to serve not only an anaphoric function, but also a deictic function. ${ }^{12}$ In Example (1), three instances of personal pronouns (i.e. wo 'I', $n \check{r}$ 'you', and wormen de 'our') are strategically used to establish a close relationship with current and potential consumers.

\section{[1]}

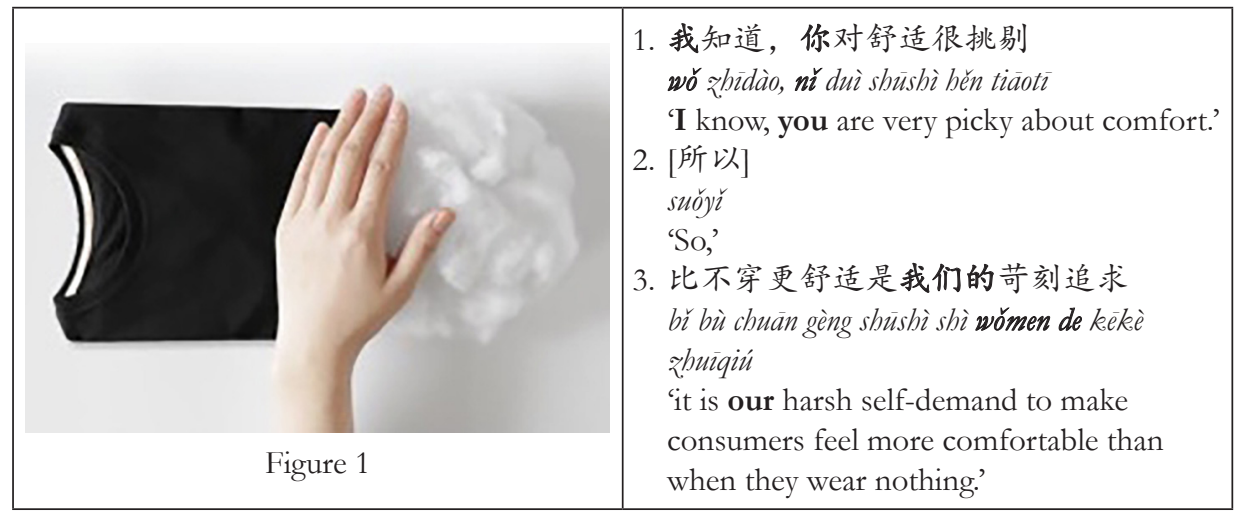

As the visual image in Fig. 1 shows, the promoted product is a black t-shirt. In this figure, a hand is placed between the t-shirt and a ball of cotton. As we can see in lines 1 and 3 , the word shüshi 'comfort, comfortable' is used twice to imply the pure cotton is soft to the touch. Thus, the conceptual scenario is that the fabric of the t-shirt is as comfortable as cotton. To convey this message to current and potential consumers, three instances of personal pronouns are used. In line 1, the first-person

11 S.C. Levinson, Pragmatics, Cambridge 1983.

12 C. Kitagawa, A. Lehrer, Impersonal uses of personal pronouns, "Journal of Pragmatics" 1990, vol. 14, no. 5, pp. 739-759; Y.-O. Biq, The multiple uses of the second person singular pronoun ni in conversational Mandarin, "Journal of Pragmatics" 1991, vol. 16, no. 4, pp. 307-321. 
singular pronoun $w o^{2}$ ' $\mathrm{I}$ ' and the second-person singular pronoun $n \iota$ ' 'you' are used. While the use of wó 'I' helps to express "sincerity" and the "personal belief" of a speaker, ${ }^{13}$ and in our case, to express those of the seller, the use of $n{ }^{r}$ 'you' helps to create solidarity with one's audience ${ }^{14}$ and in our case, with a current or to the potential consumer. Furthermore, wǒ ' $\mathrm{T}$ ' is embedded in the pattern of wor z̧hidà 'I know,' which is frequently used in persuading and requesting "to indicate that the input information is accessible or to make the potential information explicit". ${ }^{15}$ In other words, by using the personal pronouns $w o^{r}$ 'I' and $n \iota$ ' 'you,' the seller successfully shows their understanding of the needs of current and potential consumers in a sincere and intimate manner.

Interestingly, while the seller uses wor ' $\mathrm{I}$ ' as a self-reference in line 1, they switch to wormen de 'our' when talking about the efforts they have made to make the product more comfortable. As the use of the audience-exclusive we implies an instant claiming of collective opinions, the use of this pronoun bears "the power and authority of numbers". ${ }^{16}$ More specifically, this investment in a product is not made by a single person, but by a group of people, and thus the statements become trustworthy.

In our data, we also observed that the first-person plural pronoun wormen 'we' is used to include both the seller and current and potential female consumers as a whole. This is done to express closeness and solidarity with all women who are interested in the promoted item.

[2]

The visual image in Fig. 2 presents a beautiful and fashionable woman dressed in sportswear on a yacht during the summer. In lines 1-7, we see that the conceptual scenario presented is that the sportswear is exclusively designed for women. While all the advantages of the product are described with words, as we can see in the textual message, the seller is attempting to build rapport with current and potential female consumers, as manifested in his/her use of the first-person plural pronoun wömen 'we'. In line 4, this instance of wǒmen 'we' is used to refer to the seller and

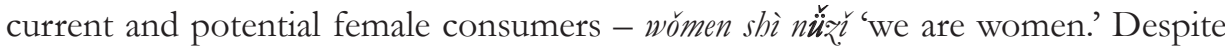
the fact that the biological sex of the seller still remains unknown, the use of this personal pronoun shows that the seller is on the side of women and understands

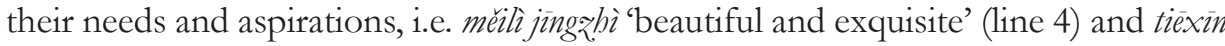
de wènnuăn 'intimate warmth' (line 5).

13 J. Wilson, Politically Speaking: The Pragmatic Analysis of Political Language, Oxford 1990.

14 S.-H. Kuo, From solidarity to antagonism: The use of the second-person singular pronoun in Chinese political discourse, "Text” 2002, vol. 22, no. 1, pp. 29-55.

15 Z. Wu, L. Li, Z. Liu, The semantic and pragmatic analysis of 'wo zhidao (I know)' in fictional style [in:] Chinese Lexical Semantics: 16 $6^{\text {th }}$ Workshop, CLSW 2015, Beijing, China, May 9-11, 2015, Revised Selected Papers (Lecture Notes in Computer Science), eds. Q. Lu, H.H. Gao, Cham 2015, p. 379.

16 R.T. Lakoff, Talking Power: The Politics of Language, New York 1990, p. 190. 


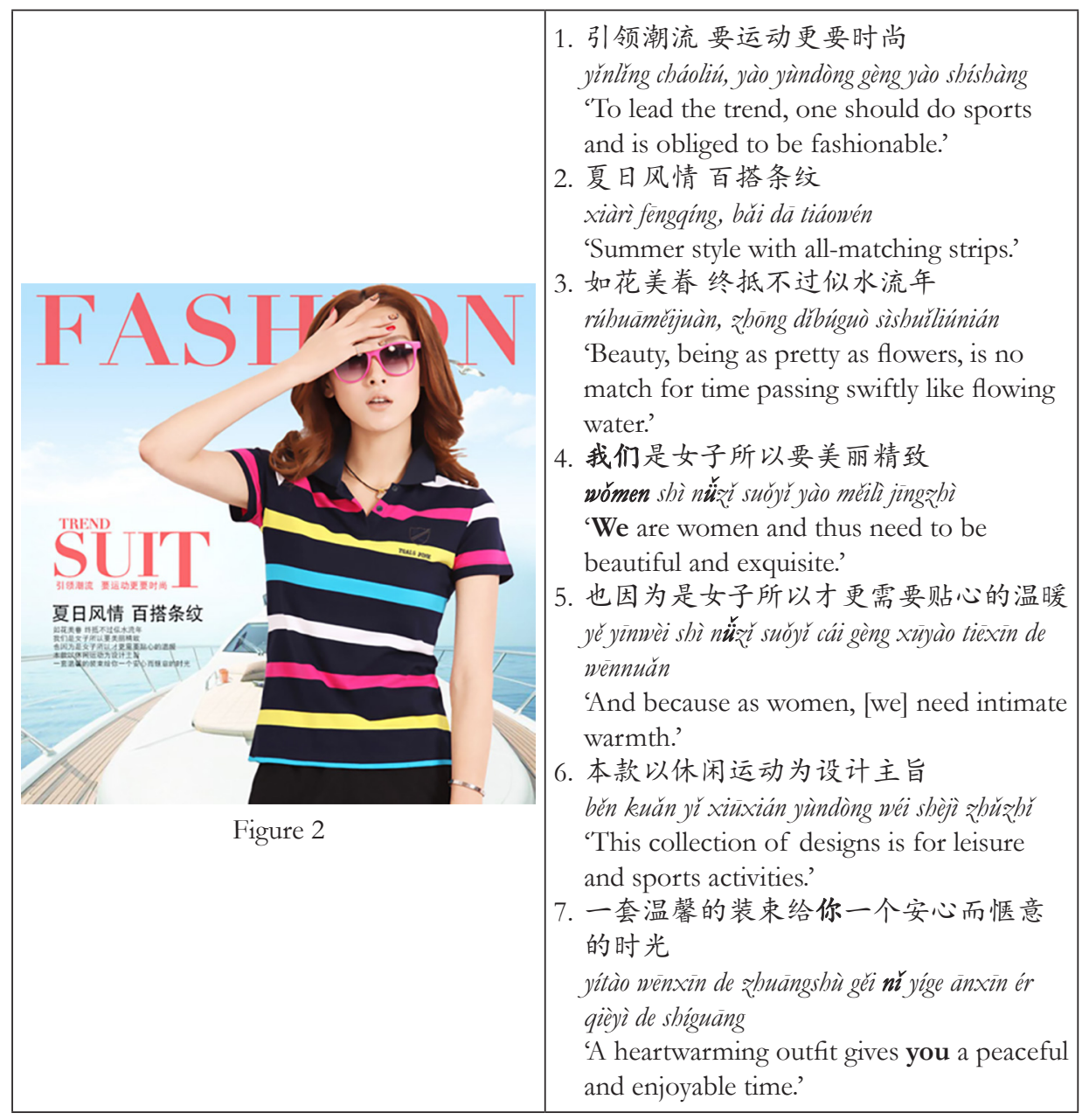

Pennycook has argued that a speaker may build rapport with their audience by using the inclusive we to assume "the shared communality". ${ }^{17}$ Lakoff has also observed that "[the] inclusive we is a powerful emotional force, bringing speaker and hearer together as one, united and sharing common interests". ${ }^{18}$ By showing an understanding of all current and potential female consumers, the seller may promote their products more effectively.

In our data, we have also observed that the first-person singular pronoun wor ' $\mathrm{I}$ ' can be used to refer to each male consumer who is reading the advertisement. This is done to voice the needs of this male consumer to show understanding of them.

17 A. Pennycook, The politics of pronouns, "ELT Journal" 1994, vol. 48, no. 2, p. 176.

18 R.T. Lakoff, Talking Power..., p. 190. 
[3]

\begin{tabular}{|c|c|}
\hline 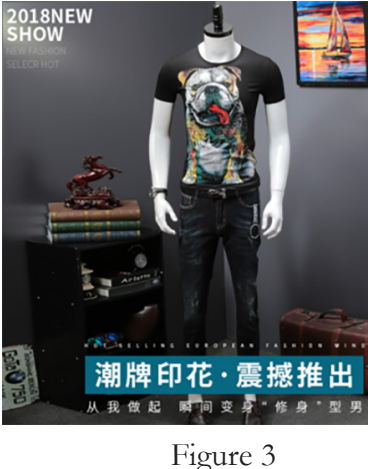 & 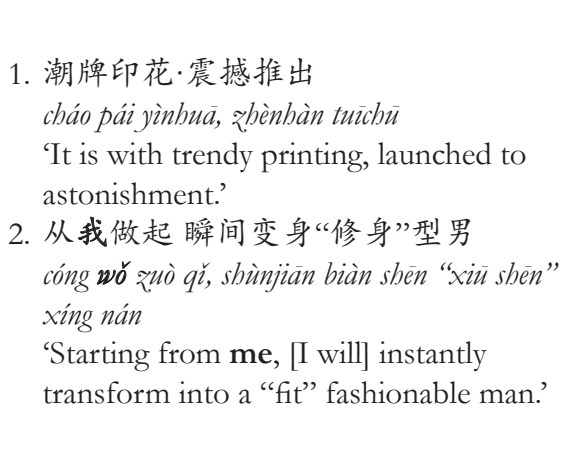 \\
\hline
\end{tabular}

The visual image in Fig. 3 shows a mannequin dressed in a tight black t-shirt with a trendy printed image of a bulldog on the front. From the textual message, it is clear that the advertisement shows not only a trendy t-shirt, but also highlights the benefits of wearing it. As such, the conceptual scenario presented is that this t-shirt may make any man who wears it instantly transform into a fit and fashionable man - a sentiment expressed in line 2 .

The seller is seen to be voicing the inner thoughts of individual male consumers through use of the first-person singular pronoun wǒ 'I,' as in cóng wǒ quò q from me." Instead of using $n \check{r}$ 'you, singular' or nǐmen 'you, plural' to directly refer to male consumers, the seller has chosen the first-person singular pronoun wo' 'I' to enact the role of an individual male consumer and to dramatize the speech event. According to Kuo, "the dramatic use of personal pronouns is a rhetorical device for more vividly presenting the described situation". ${ }^{19}$ In other words, the seller can be regarded as talking on behalf of potential male consumers. By using wor ' $\mathrm{T}$ ' to talk on behalf of those male consumers, the seller not only assumes their understanding of consumer's needs, as they voice their inner thoughts, but also vividly present their needs.

\subsection{The use of questions}

Questions are not always used to seek a response. According to Ilie, there are three recurring types of non-standard question in contrast to standard response-eliciting questions: expository questions, rhetorical questions, and echo questions. ${ }^{20}$ Of these three types of questions, rhetorical questions can be used to embody the inner speech of current and potential consumers.

19 S.-H. Kuo, Involvement vs. detachment: Gender differences in the use of personal pronouns in televised sports in Taiwan, "Discourse Studies" 2003, vol. 5, no. 4, p. 487.

20 C. Ilie, Question-response argumentation in talk shows, "Journal of Pragmatics" 1999, vol. 31, no. 8, pp. 975-999. 


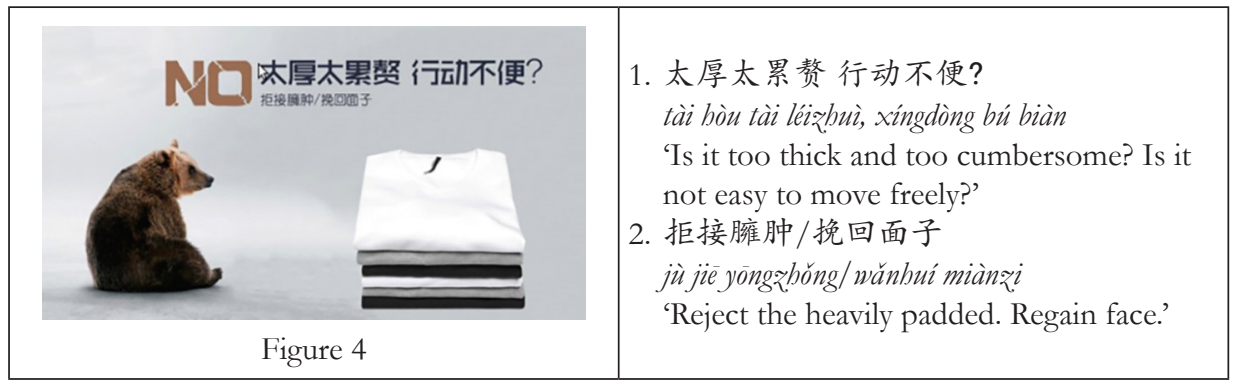

As we can see in the visual image in Fig. 4, there is a bear sitting on the left and looking at a pile of t-shirts on the right. The conceptual scenario presented in the textual message is that while the bear may symbolize a heavily padded consumer, the pile of t-shirts at which the bear is looking symbolizes the solution. To reflect the inner speech of those helpless consumers who happen to have the same problem, a rhetorical question is used, as we can see in line 1. This question is asked as if the seller has heard the question from one of these consumers and is repeating it. Clearly, it represents the inner speech of these consumers.

Inner speech, as defined by Alderson-Day and Fernyhough, is "the subjective experience of language in the absence of overt and audible articulation" and may be referred to as "private speech, self-talk, covert speech, silent speech, verbal thinking, verbal mediation, inner monologue, inner dialogue, inner voice, articulatory imagery, voice imagery, speech imagery, and auditory verbal imagery". ${ }^{21}$ By using a rhetorical question, the private thoughts of the consumer are embodied. In addition, when voicing the inner thoughts of these consumers, the seller also shows their understanding of their problems. This is done to further connect the solution to the promoted item.

\section{Creating humor}

Humor is a psychological coping mechanism. According to Weems, humor results from "a battle in our brains between feelings and thoughts - a battle that can only be understood by recognizing what brought the conflict on". ${ }^{22}$ As further observed by Martineau, humor can be used to shape human interactions in intra-group situations, inter-group situations, and inter-group interactions. ${ }^{23}$

\footnotetext{
21 B. Alderson-Day, C. Fernyhough, Inner speech: Development, cognitive functions, phenomenology and neurobiology, "Psychological Bulletin" 2015, vol. 141, no. 5, pp. 931-932.

22 S. Weems, Ha!: The Science of When We Laugh and Why, New York 2014, p. 9.

23 W.H. Martineau, A model of the social functions of humor [in:] The Psychology of Humor: Theoretical Perspectives and Empirical Issues, eds. J.H. Goldstein, P.E. McGhee, New York 1972, pp. 101-125.
} 
Despite the fact that Chinese people have traditionally been viewed as serious and mysterious regarding humor ${ }^{24}$ in our data we observed that many sellers promote their products by creating humor, mainly through the use of episodization and neologisms.

\subsection{The use of episodization}

As observed by Chen in analyzing conversational humor, a fictional episode is "an imagined situation created by a speaker for a specific communicative purpose, in these cases, with a humorous effect". ${ }^{25}$ In our data, the seller may create a funny fictional episode to promote their product. In so doing, the seller may successfully catch the attention of their potential consumers. Example (5) illustrates this point.

[5]

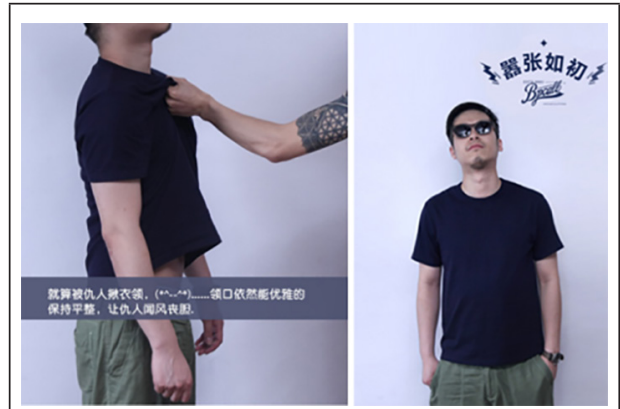

Figure 5
1. 就算被仇人揪衣領, jüusuàn bèi chóurén jiū yizlüng 'Even if [you] are grabbed by the collar by a foe,'

2. 領口依然能优雅的保持平整, lǐngkǒu yìrán néng yoüuyà de bǎochí pingşèng 'the collar still remains smooth and elegant,'

3. 让仇人闻风丧胆。 ràng chóurén wénfèngsàngdàn 'leaving the foe trembling with fear.'

The visual image in Fig. 5 is composed of two episodes. In the first episode, we see a man in a black t-shirt being grabbed by the collar by a hand with a tattoo. Chinese people, in general, have a negative attitude towards tattoos and those with tattoos - tattoos are seen as rebellious symbols and a form of self-stigmatization with violence. ${ }^{26}$ As such, the hand with a tattoo may be considered to symbolize a gangster or someone to be feared. In the second episode, however, the man in the black t-shirt appears not to be threatened at all by the gangster, as shown by his superior and sneering expression. In lines $1-3$, moreover, we know that the man in the black t-shirt does not fear the gangster because his collar remains

24 K.-Y. Shi, Wu-wei: The non-doing philosophy in Chinese humor, "Research Papers in Linguistics and Literature" 1996, vol. 5, pp. 87-98.

25 L.-C. Chen, Taiwanese and Polish Humor: A Socio-Pragmatic Analysis, Newcastle upon Tyne 2017, p. 64.

26 E. Ma, Emotional energy and sub-cultural politics: Alternative bands in post-1997 Hong Kong, "InterAsia Cultural Studies” 2002, vol. 3, no. 2, pp. 187-200. 
smooth and elegant, which leaves his foe trembling with fear. From both the visual and textual messages we can see that the conceptual scenario is that the collar of the promoted item will always remain smooth even if the buyer is grabbed by it. While this promotional strategy can be regarded as wúlitóu 'nonsense', ${ }^{27}$ it focuses the attention of current and potential consumers on a product benefit in a humorous way.

\subsection{The use of neologisms}

New words are constantly entering our lexicon to describe new concepts, new technology, and the new world. In our data, we observed that neologisms were used in texts to attract the attention of young consumers to promote products due to their funny nature. In addition, the use of neologisms in advertising also reflects how culture is evolving, as shown by the following example.

[6]

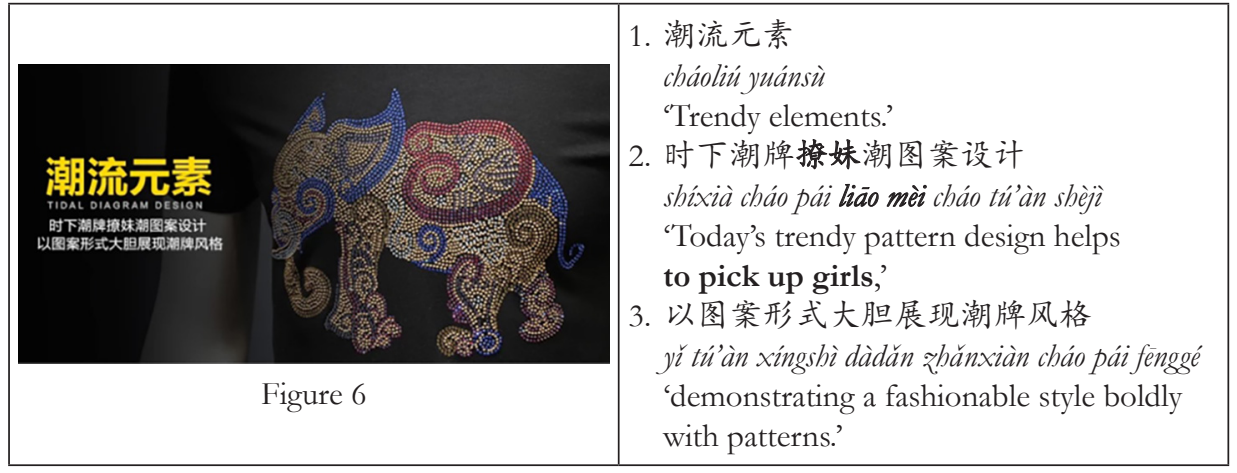

The visual image in Fig. 6 is of a man wearing a black t-shirt with an elephant, which is composed of geometric patterns of various bright colors. The combination of these bright colors is presented by the seller as cháoliú yuánsù 'trendy elements' (line 1), demonstrating a bold fashionable style (line 3). In line 2, however, the function of this design is enhanced by the use of a new word liāo mèi 'to pick up girls' in liāo mèi cháo tú'àn shèjì 'a trendy pattern design that helps to pick up girls.' Thus, the conceptual scenario is that wearing this t-shirt may make the male buyer(s) more attractive.

Due to China's one-child policy, which was first introduced in 1979, China has many million more men than women and millions of Chinese men remain single. Although the one-child policy was later replaced by the two-child policy in 2016,

27 L.-C. Chen, A socio-pragmatic analysis of wúlitón 'nonsense' in Taiwanese verbal interactions, "Lodz Papers in Pragmatics" 2016, vol. 12, no. 1, pp. 53-76; idem, Taiwanese and Polish Humor... 
its legacy lives on. ${ }^{28} \mathrm{It}$ is thus considered necessary for a young man to attract the attention of a woman. The seller promotes such a design as having the potential to help a man win a girl's heart.

Algeo has argued that language can serve as a marker of history and may reflect back culture as it changes. ${ }^{29}$ In addition, neologisms can be used to understand how culture is evolving. As Algeo has further explained: "A community is known by the language it keeps, and its words chronicle the times. Every aspect of the life of a people is reflected in the words they use to talk about themselves and the world around them. As their world changes - through invention, discovery, revolution, evolution or personal transformation - so does their language. Like the growth rings of a tree, our vocabulary bears witness to our past". ${ }^{30}$

By adding neologisms to advertisements, humor can also be created. A thoughtful smile can be triggered in consumers when products are promoted in this way and, as Liao (2001) points out, for Chinese people humor is a good thing as it has both entertaining and educational functions. ${ }^{31}$

3. Suggesting the advantages of purchasing a product

It is commonly agreed that creators of advertisements tend to resort to hidden forms of influence on mass consciousness, which is known as speech manipulation. For the purposes of this study we have adopted the definition of speech manipulation proposed by Gurochkina, who emphasizes the setting of the addressees to appeal to the audience's emotions and the use of an indirect, allegorical way of submitting information with the aim of imposing covertly a certain idea of reality on the addressees. ${ }^{32}$

\subsection{The use of implication}

Implicit advertising relies on subtle means to deliver a seller's message. The components of the message are not clearly stated. Rather, implicit advertising encourages consumers to draw their own conclusions. One of the ways that implicit marketing tries to get consumers to buy products without using pushy advertising

${ }^{28}$ F. Wang, B. Gu, Y. Cai, The end of China's one-child policy, "Studies in Family Planning" 2016, vol. 47, no. 1, pp. 83-86.

29 J. Algeo, Fifty Years among the New Words: A Dictionary of Neologisms, 1941-1991, Cambridge 1991.

30 Ibidem, p. 1.

31 C.-C. Liao, Taiwanese Perceptions of Humor: A Sociolinguistic Perspective, Taipei 2001.

32 A.G. Gurochkina, Manipulirovanie v lingvistike [Manipulation in linguistics], "Izvestiya Rossiiskogo Gosudarstvennogo Pedagogicheskogo Universiteta im. Aleksandr I. Gertsena" 2003, vol. 3, no. 5, pp. 136-141. 
methods is by using pictures of celebrities, pictures of beautiful women, or those of successful men. Consumers often seek to identify with a character in advertising. The implicit messages in advertisements may cause viewers to see the products advertised as being symbolic of other concerns, such as status or personal attractiveness.

\section{[7]}

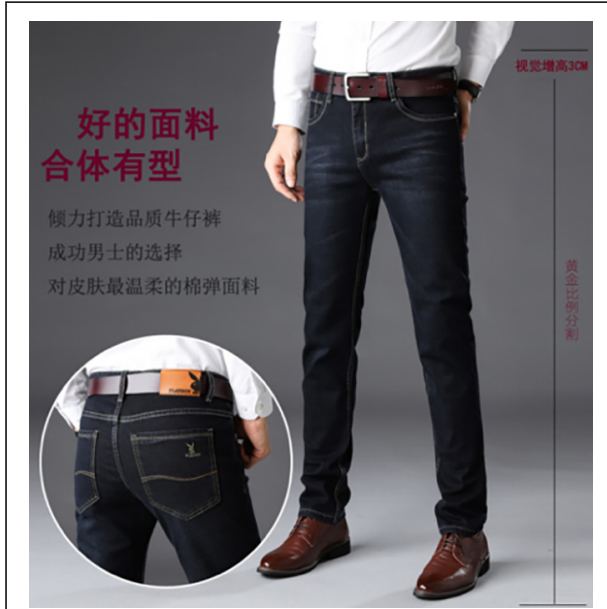

Figure 7
1. 好的面料 hǎo de miànliào

'Fine fabric.'

2. 合体有型 béť̌ yǒuxing

'Fit and stylish.'

3. 倾力打造品质牛仔裤 qingli dăzào pìnzhí niúzáikù

'All efforts are made to create high-quality jeans.'

4. 成功男士的选择 chénggōng nánshì de xuănzé

'The choice made by successful men.'

5. 对皮肤最温柔的棉弹面料

duì pífū zuì wēnrón de mián tán miànliào

'Cotton fabric that is gentle on the skin.'

The visual in Fig. 7 shows a man wearing a stylish pair of jeans. In the text, while lines 1, 2, 3, and 5 focus on the quality of the jeans and on their design, line 4 implies that any man who purchases this product will be a successful man, inviting both current and potential male consumers to connect themselves to the idea of a successful man. In other words, the conceptual scenario presented is that purchasing this stylish pair of jeans will help one achieve success. This scenario is constructed using implication, as no direct reference is made. This advertisement simply implies that a successful man would choose to buy this product.

\subsection{The use of neologisms}

As discussed previously, language can serve as a marker of history and may reflect culture as it changes. ${ }^{33}$ Neologisms can also be used to suggest the advantages of purchasing particular products.

33 J. Algeo, Fifty Years... 


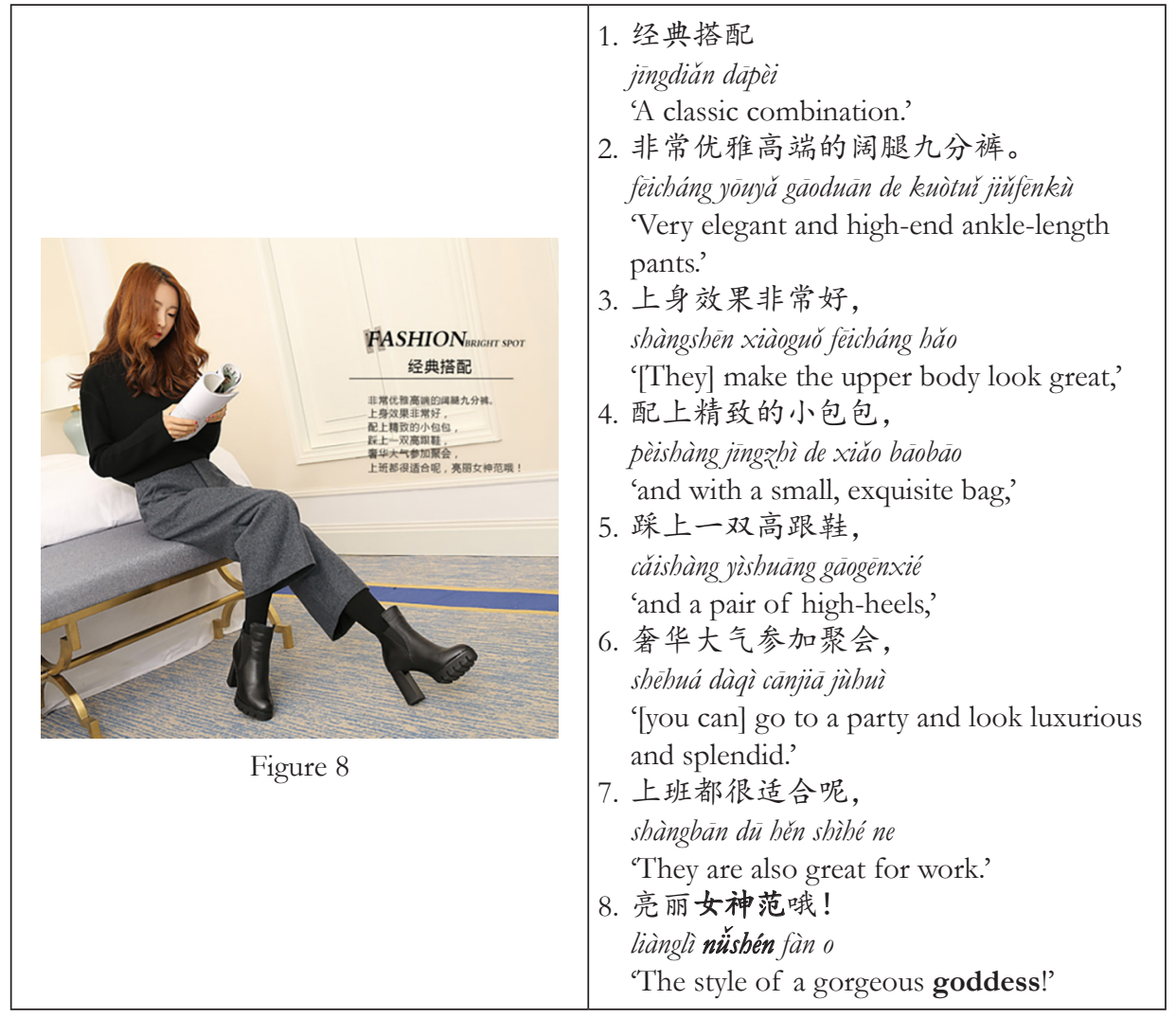

In the visual image in Fig. 8 we see an elegant woman reading while leisurely sitting on a chair. In line 2 , we know that the promoted product is a pair of ankle-length pants worn by the woman. While the text focuses on the possible effects of wearing ankle-length pants and their suitability for various occasions (e.g. for work or parties), a neologism is used to suggest one of the advantages of purchasing the promoted product. In line 8 the term nü̈shén 'goddess' is used to portray any woman who purchases the item to be a goddess, suggesting that anyone who sees her would instantly notice her and be both attracted to and intimidated by her. In other words, the use of this term helps to construct a potential female consumer's image in a positive manner to encourage the product's purchase. The conceptual scenario presented here is that any woman who purchases this item and wears it will immediately attract the attention of other people.

We have observed similar neologisms in our data, including: nánshén 'male god' (to refer to an unattainably handsome man); nuãnnán 'warm man' (to refer to a considerate man who makes people warm); and cháonán 'trendy man' (to refer to a met- 
rosexual man). All these neologisms are used to construct current and potential consumers in a positive manner.

\section{Highlighting the benefits of a product}

To successfully sell a product, it is very important to highlight its benefits. In our data, we observed that sellers were inclined to use metaphors, assertives, and indirectness to highlight the product benefits.

\subsection{The use of metaphors}

Lakoff and Johnson's pioneering work pointed out that how people think or act is metaphorical by nature and that metaphors pervade our daily lives. ${ }^{34}$ Among various metaphors, personification, by which nonhuman entities are specified in terms of "human motivations, characteristics, and activities" to aid understanding, is the most prominent ontological metaphor. ${ }^{35}$ In our data, we observed that personification was frequently used to specify the quality of promoted products.

[9]

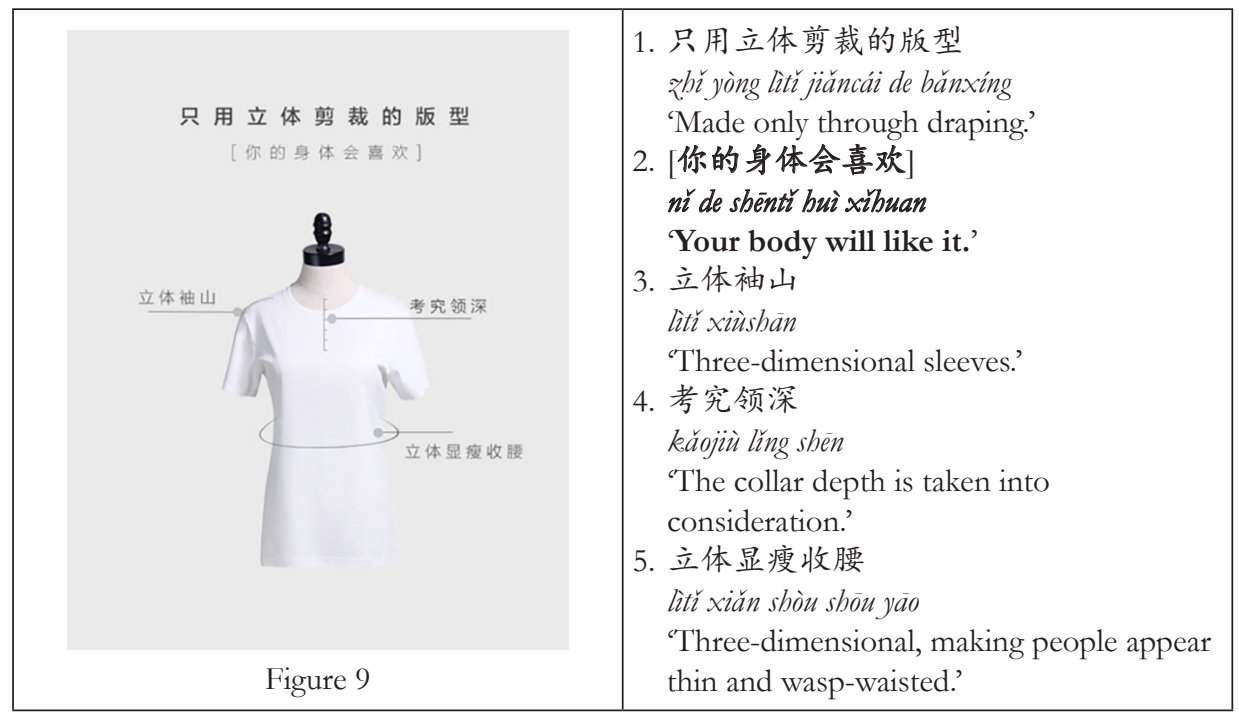

The image in Fig. 9 presents and describes a white t-shirt, including the use of draping (line 1), three-dimensional sleeves (line 3), the collar depth (line 4), and its effect (line 5). In line 2, the consumer's body is further specified as a person who can

34 G. Lakoff, M. Johnson, Metaphors We Live By, Chicago 1980.

35 Ibidem, p. 33. 
perform the action of "liking." By personifying the consumer's body, the comfortable sensation of wearing this t-shirt is vividly embodied. The conceptual scenario is that the promoted item not only makes its buyer look thin, but that it is also comfortable.

Interestingly, it is not just the consumer's body that is personified. The promoted product can also be personified as akin to a close friend.

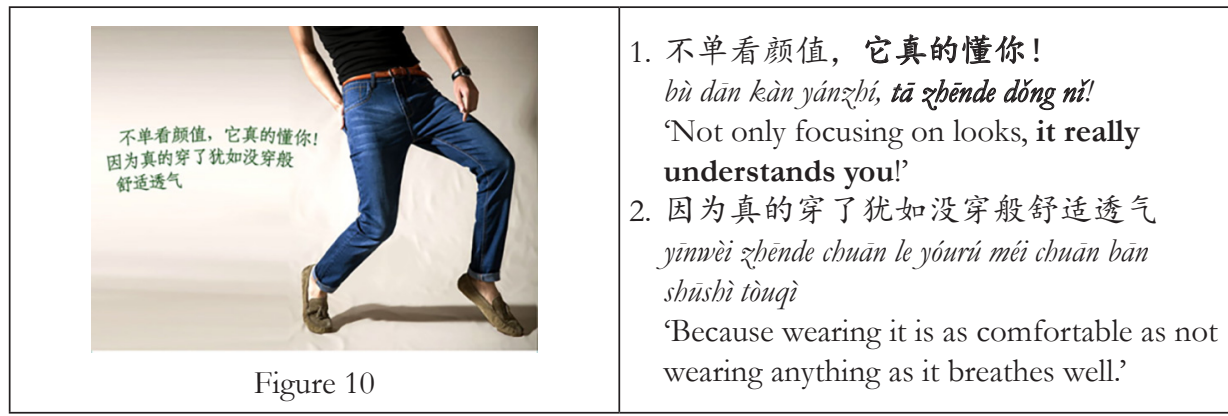

The visual image in Fig. 10 shows a man wearing a pair of jeans, revealed only from the waist down. While the text highlights the benefits of the product (see line 2), the pair of jeans is personified as a close friend who understands the consumer's needs. The conceptual scenario is that the promoted item is not only stylish, but also comfortable, as shown in the use of the verb dóng 'understand.' By specifying the pair of jeans as a close friend, the consumer immediately knows that this pair of jeans is especially designed for him, and that it "understands" what he needs.

In our data, we also observed that the effect of wearing a promoted product can be specified as a running person who cannot be stopped. This was done to better express the complicated concept of "handsomeness," as illustrated in the following example.

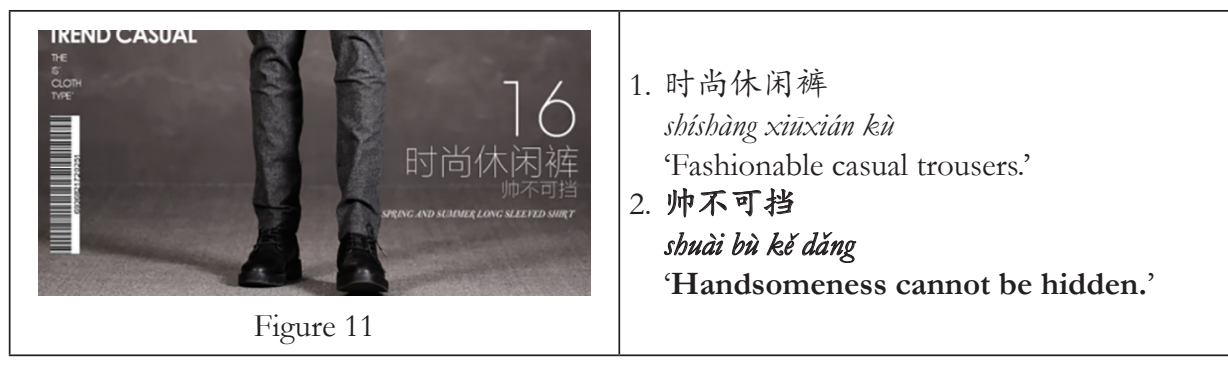

The image in Fig. 11 shows only the legs of a man wearing trousers. From the text we know that the promoted product is a pair of trousers for men (line 1). In line 2, the effect of wearing this pair of trousers is specified as a running person, 
as shown by the use of the verb danng 'to block, to stop.' More specifically, a man's attractiveness as revealed by his trousers cannot be hidden, which is presented as being like a person running who cannot be stopped. The conceptual scenario is that a man who wears this pair of trousers will become extremely handsome.

\subsection{The use of assertives}

The main challenge faced by marketers is converting an onlooker of an advertisement into a consumer. A method used in many advertisements today is the creation of a sense of urgency. This is done by using assertive language. Assertiveness, according to the Oxford Advanced Learner's Dictionary of Current English, is when statements appear "confident and forceful". 36

[12]

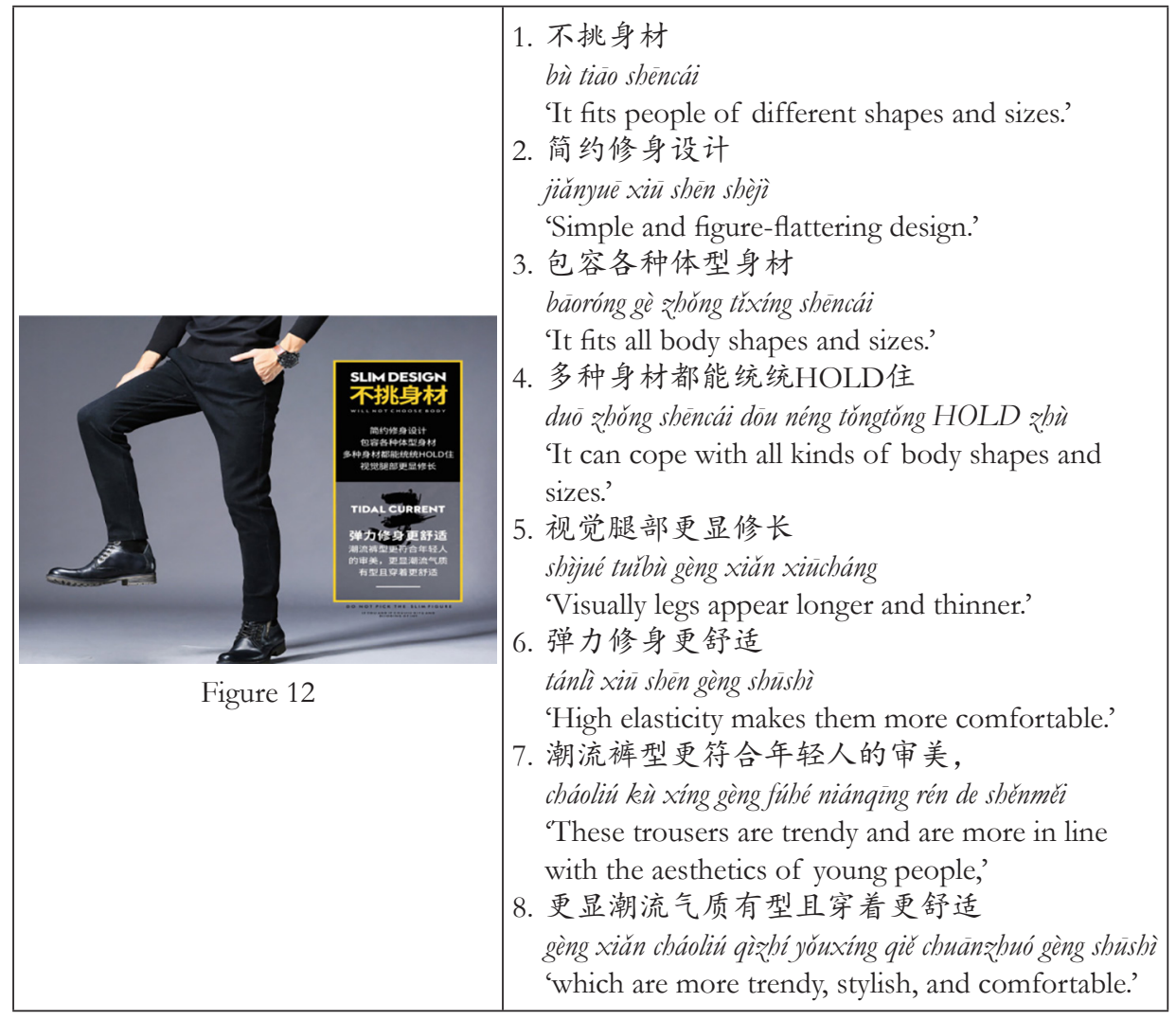

36 J. Turnbull, D. Lea, D. Parkinson, P. Phillips, B. Francis, S. Webb, V. Bull, M. Ashby, Oxford Advanced Learner's Dictionary of Current English, $8^{\text {th }}$ ed., Oxford 2010, p. 74. 
The image in Fig. 12 presents a man wearing a black pair of trousers. The textual message consists of various positive features of the product, as well as the benefits of wearing it, including bù tiāo shèncái 'it fits people of different shapes and sizes' (line 1) and jiănyuè xiù shèn shèjì 'simple and figure-flattering design' (line 2). The conceptual scenario presented is that the promoted item has many positive features. However, the seller simply asserts these aspects to be true, rather than using commissives - promises or commitments of some sort - to guarantee the benefits of purchasing the item. The positive features of the product and the benefits of wearing it are presented as self-evident and not requiring further proof, leaving potential consumers to choose to believe the statements made or not. This is done to avoid potentially unavoidable risks when using commissives. For example, a consumer who has purchased this black pair of trousers and does not find the product benefits as effective may issue a complaint. In fact, most advertisements in our data were created using this strategy. Additionally, to avoid potential difficulties, using assertives also helps consumers to make their decision by clearly stating the product features and benefits.

\subsection{The use of indirectness}

Pragmatic politeness theories argue that indirectness and politeness are related to each other. ${ }^{37}$ In studying politeness phenomena in modern Chinese, Gu further argued that there are four notions that underlie the Chinese concept of limà 'politeness,' including 'respectfulness, modesty, attitudinal warmth, and refinement". ${ }^{38}$ Among these, modesty can be regarded as self-denigration. More specifically, Chinese people seem to be more willing to elevate their interlocutors and lower themselves.

In analyzing Japanese, Korean, Chinese, and Thai written discourse, Hinds (1990) has also pointed to sociocultural, historical, sociopolitical, and situational constraints as the source of rhetorical differences between these languages. ${ }^{39}$ As he has further observed, direct argumentation and persuasion tend to be avoided in writing in these languages, in the sense that indirectness helps to maintain harmony and avoid impositions on both the writer and the reader. Obviously, it may be considered improper to highlight product benefits directly in advertising in Chinese culture. As such, promoting products indirectly is often preferred.

37 G.N. Leech, Principles of Pragmatics, New York 1983; P. Brown, S.C. Levinson, Politeness: Some Universals in Language Usage, Cambridge 1987.

38 Y. Gu, Politeness phenomena in modern Chinese, "Journal of Pragmatics" 1990, vol. 14, p. 239.

39 J. Hinds, Inductive, deductive, quasi-inductive: Expository writing in Japanese, Korean, Chinese, and Thai [in:] Coherence in Writing: Research and Pedagogical Perspectives, eds. U. Connor, A.M. Johns, Alexandria, VA 1990, pp. 87-110. 


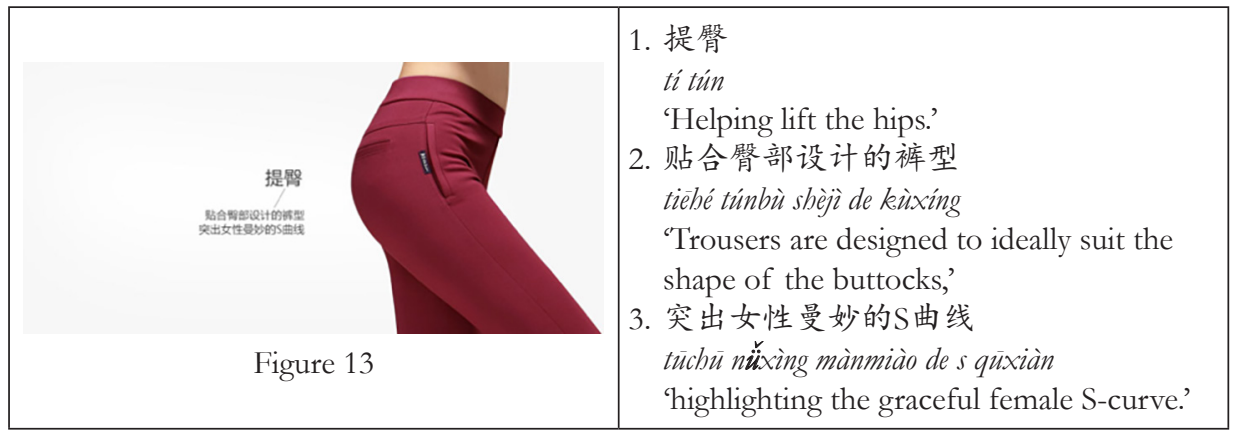

The image in Fig. 13 shows a woman wearing a red pair of trousers, with a special focus on the hips to highlight the model's S-curve as well as the promoted item. As we can see in lines 1-3, only the functions and possible effects are mentioned. The conceptual scenario is that the promoted item may help its buyer, a woman, look sexier. The seller, however, does not use any self-reference in the textual message. This is perhaps because self-elevation is considered to run contrary to social norms in China. As such, it is improper to highlight one's product benefits directly and consumers have to infer these benefits by themselves. Indeed, as Matalene has observed, the defining characteristic of Chinese rhetoric is "to expect the audience to infer meanings rather than to have them spelled out". 40

It is improper to highlight the product benefits while at the same time directly pointing out the flaws of current and potential consumers. To avoid this, agentless constructions are used in the textual message.

[14]

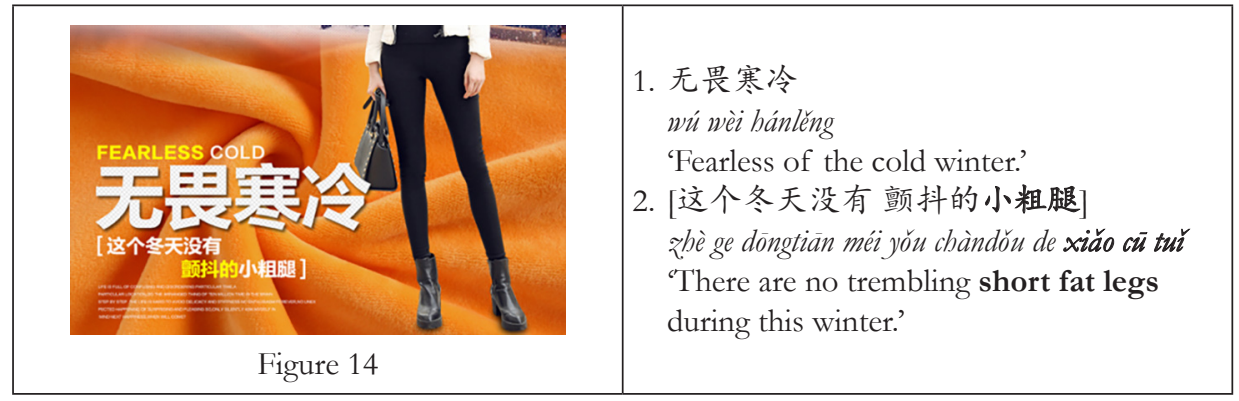

The image in Fig. 14 consists of a woman with slender legs. While line 1 highlights protection from cold weather, line 2 implies that the promoted product can

40 C. Matalene, Contrastive rhetoric: An American writing teacher in China, "College English" 1985, vol. 47 , no. 8 , p. 801. 
also help female consumers with fat legs to look slender. Here, the conceptual scenario is that the promoted item may help a fat-legged woman look thin. While the textual message highlights the function of the product, it perhaps also criticizes potential consumers indirectly and suggests that those with short, fat legs need to buy the promoted product. Although not all of them may have short, fat legs, that does not stop these female consumers from worrying about them. The advertisement, thus, also plays on bodily insecurity. In line 2, however, the second-person pronouns are strategically omitted to avoid face-threatening acts, as in méi yóu chàndǒu de xiǎo си tuг 'there are no trembling short fat legs.' Thanks to this agentless construction, the flaws of current and potential consumers are only pointed to indirectly, while at the same time the product benefits are highlighted. In addition, this line can also be regarded as humor for those who do not mind self-mocking.

\section{Conclusion}

Due to extensive use of smartphones in modern Chinese society, electronic commerce has become a significant part of the market. To attract current and potential consumers' attention, many product promotional strategies are used. If a seller fails to advertise their products or services effectively, it will be difficult for their business to succeed. To survive in the competitive Chinese business world, many online sellers need to promote their products strategically - in particular using advertisements. Understanding what makes a particular advertisement effective allows one to tailor their own marketing plans and achieve better results. It is important to analyze product promotional strategies using a multimodal fusion model (Lin and Chiang 2015), ${ }^{41}$ as this model combines the conceptual, visual, and verbal modes to help us fully understand the cognitive mechanism encoded in Chinese online advertisements.

Analyzing the data, we observed four strategies used by Taobao sellers to promote their products in their advertisements, including: 1) expressing closeness and solidarity with current and potential consumers; 2) creating humor; 3) suggesting the advantages of purchasing a product; and 4) highlighting the benefits of a product. To express closeness and solidarity with current and potential consumers, personal pronouns and questions are frequently used. Episodization and neologisms are used to create humor. To suggest the advantages of purchasing a product, implication and neologisms are used. Finally, we also observed that sellers are more inclined to use metaphors, assertives, and indirectness when highlighting a product's benefits.

This study contributes to the current understanding of how online advertising affects potential consumers and what tactics are used by sellers to become market

41 T.Y.-Y. Lin, W.-Y. Chiang, Multimodal fusion... 
leaders in a particular industry. Although many previous studies have shed light on online advertising, a holistic multimodal analysis of product promotional strategies on a Chinese online shopping website has not been undertaken before. In addition, since our analytical model is data-driven, it can be applied to future studies on Chinese online advertising. Our findings constitute a helpful resource for people planning to develop their business in the Chinese market, as well as for researchers interested in this field.

\title{
STRESZCZENIE
}

\section{STRATEGIE PROMOCJI PRODUKTÓW NA STRONIE CHIŃSKIEGO SKLEPU INTERNETOWEGO: MODEL FUZJI MULTIMODALNEJ}

\begin{abstract}
Zakupy online, jako forma elektronicznego handlu, pozwalają kupującym na bezpośredni zakup produktu lub usługi od sprzedawcy bądź sklepu internetowego za pomoca przeglądarki internetowej. W artykule porównano sto reklam ubrań z chińskiego portalu zakupowego Taobao (taobao.com), zawierających obraz/obrazy oraz tekst, co miało na celu ukazanie i wyjaśnienie, jak sprzedawcy i sklepy internetowe reklamują swoje produkty. Za analityczną ramę posłużył model fuzji multimodalnej, w którym łączą się tryby konceptualne, wizualne i werbalne. Dokonujacc analizy danych, zaobserwowano cztery strategie lingwistyczne używane przez sprzedawców na Taobao w celu promocji produktów. Sa to: 1) wyrażanie bliskości i solidarności z obecnymi i przyszłymi klientami; 2) odwoływanie się do poczucia humoru; 3) sugerowanie korzyści wynikłych z zakupu produktu; oraz 4) podkreślanie zalet produktu. W celu wyrażenia bliskości i solidarności z obecnymi i przyszłymi klientami używane sa zaimki osobowe oraz pytania. Humor tworzony jest za pomoca epizodyzacji i neologizmów. Aby zasugerować korzyści wynikające z zakupu, sprzedawcy stosują implikacje i neologizmy. Zaobserwowano także, że sprzedawcy, aby podkreślić zalety produktu, stosuja metafory, asercję oraz pośredniość.
\end{abstract}

